\title{
In vitro micrografting of lucumo (Pouteria lucuma), Sapotaceae
}

\author{
Jeanine Córdova-Risco, Consuelo Rojas-Idrogo, Guillermo E. Delgado-Paredes*
}

Facultad de Ciencias Biológicas, Universidad Nacional Pedro Ruiz Gallo, Ciudad Universitaria, Juan XXIII No 391, Lambayeque, Perú

${ }^{*}$ Corresponding author, E-mail: guidelg2015@yahoo.es

\begin{abstract}
Effects of plant growth regulators [gibberellic acid $\left(\mathrm{GA}_{3}\right)$ and indole-3-butyric acid (IBA)], holding grafts (aluminum foil and cooper wire), pre-treatment [immersion in $1.5 \mathrm{mg} \mathrm{L}^{-1}$ 6-benzylaminopurine (BAP)] of scions, and genotype combination (rootstock $\times$ scion) were investigated on micropropagation of rootstocks and scions and micrografting of lucumo (Pouteria lucuma) cv. 'Beltrán' and 'Seda'. In vitro germinated commercial lucumo seedlings developed from seeds were used as rootstocks and scions. The rootstocks were cultured

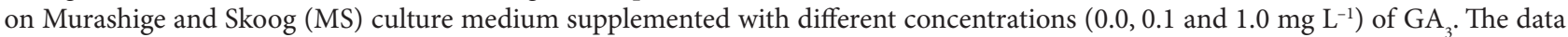
showed that in the cv. 'Beltrán' the maximum shoot height $(6.1 \pm 1.2 \mathrm{~cm})$ and nodes formed (7) were observed in the presence of 0.1 $\mathrm{mg} \mathrm{L}^{-1} \mathrm{GA}_{3}$. The effects of two different MS media containing $0.1 \mathrm{mg} \mathrm{L}^{-1} \mathrm{GA}_{3}(\mathrm{MM}-1)$ and $0.1 \mathrm{mg} \mathrm{L}^{-1} \mathrm{GA}_{3}$ and $0.4 \mathrm{mg} \mathrm{L}^{-1} \mathrm{IBA}(\mathrm{MM}-2)$ were studied on development of micrografted plantlets. Propagated shoots tips, were micrografted onto in vitro germinated commercial lucumo seedlings. The results indicated that the best graft rate were obtained in the genotypes combination 'Seda' $\times$ 'Beltrán' (rootstock $\times$ scion), holding grafts with cooper wire, and pre-treatment of scions with immersion in $1.5 \mathrm{mg} \mathrm{L}^{-1} \mathrm{BAP}$, reaching a survival rate of $87.5 \%$; however, in both MM-1 and MM-2 culture media the survival rate of grafting was similar (52.6 and 54.1\%, respectively).
\end{abstract}

Key words: lucumo, rootstocks, shoot elongation, scions.

Abbreviations: BAP, 6-benzylaminopurine; GA, gibberellic acid; IBA, indole-3-butyric acid; MS, Murashige and Skoog medium.

\section{Introduction}

In Peru, the Sapotaceae family comprises 10 genera (Manilkara, Sideroxylon, Ecclinusa, Micropholis, Pouteria, Sarcaulus, Chrysophyllum, Diploön, Elaeoluma and Pradosia). Genus Pouteria comprises nearly 50 species, and is the largest genus in the family and an important component of lowland rain forest (Brako, Zarucchi 1993). Pouteria caimito is one of the most widespread species and Pouteria lucuma is another widely cultivated species native in wet montane and cloud forest at 1500 to $3000 \mathrm{~m}$ alt; the globose fruit, 6 to $12 \mathrm{~cm}$ diameter, contain a rather dry yellowish-brown flesh, much used for flavouring ice-cream and cakes (Pennington et al. 2004).

Conventional propagation and breeding the lucumo is by sexual seed and grafting, but these methods have some limitations caused by the following reasons: perennial nature, long generation cycle, self-incompatibility, low success rate of hand pollination, long duration for seed maturation, clonal difference of flowering time and fruit bearing capability of some clones, high levels of heterozygosity, and others, as it was observed in Camellia sinenis (Mondal et al. 2005). Therefore, tissue culture is certainly a better alternative for conventional propagation and reduction in growth and development time; however, fruit trees are amongst the most recalcitrant for in vitro culture, and regeneration of adventitious shoots from adult explants has proven to be difficult (Miguel et al. 1996). In woody fruit trees, vegetative propagation by cuttings, is used to minimise the enormous genetic variation caused by sexual propagation; however, as rooting is of great difficulty, as observed in almond (Prunus dulcis) cultivars, micrografting has been the most widely used method for vegetative propagation (Yildirim et al. 2010). In this sense, micrografting or in vitro grafting is a relatively new technique for plant propagation which, in the classic definition of Hartmann et al. (2002), "involves the placement of a meristem or shoots tip explant onto a decapitated rootstock that has been grown aseptically from seed or micropropagated cultures". Micrografting was initially used in herbaceous plants, but then was used in particular on woody species and especially on fruit species; it was modified and improved for increasing the graft success by Murashige et al. (1972) and Navarro et al. (1975). In general, the technique has great potential for fruit plant improvement and large-scale multiplication, production of pest and systemic disease-free (such as virus, viroids, bacteria and fungi) plants, safe international germplasm exchange and multiplication of plants with problems in root system formation (Hussain et al. 2014).

In micrografting of almond (Amygdalus communis) cv. 'Nonpareil', the effect of several growth regulators on microscions micropropagation was studied, obtaining 
the highest shoot regeneration (6.66) and shoot length $(1.95 \mathrm{~cm})$ with Murashige and Skoog (MS) culture medium (Murashige, Skoog 1962) supplemented with 6-benzylaminopurine (BAP) $1.0 \mathrm{mg} \mathrm{L}^{-1}$ (Ișıkalam et al. 2011). Using micrografting, grapevine (Vitis vinifera) cv. 'Jing Xiu' was used as scion and Vitis amuensis cv. 'Shuang you', a new wild grape variety, as rootstock; from the eight micrografting methods tested, three of them presented successful root formation (formation rate $>60 \%$ ), when the shoot tip was selected as scion material (Zhu et al. 2007). In another study, the rejuvenation of mature lentisk (Pistacia terebinthus) by in vitro micrografting method was developed for the production of plantlets, and genetic stability of 3-, 6-, and 24-times subcultured clones of both male and female genotypes was assessed and compared with the mother plants using fluorescent-based amplified fragment length polymorphism analysis (Onay et al. 2016). In general, in vitro micrografting has been reported in many plants such as cashew (Anacardium occidentale) (Thimmappaiah et al. 2002), pistachio (Pistacia vera) (Onay et al. 2007), olive (Olea europaea) (Revilla et al. 1996), almond (Amigdalus communis) (Channuntapipat et al. 2003) and cherry (Prunus avium) (Amiri 2006). Reviews on micrografting have been published by Jonard et al. (1983), Jonard (1986), Roistacher et al. (1976), Navarro (1988), Parkinson et al. (1990), Monteuuis (2012) and recently by Hussain et al. (2014).

The objective of the present study was to investigate the most reliable micrografting technique, and the optimal grafting materials for lucumo. We specifically investigated the influence of BAP, holding grafts, culture medium and genotypes over the micrografting of lucumo.

\section{Materials and methods}

\section{Obtaining in vitro and ex vitro rootstocks}

The in vitro seedlings used as rootstocks were obtained from Pouteria lucuma seeds cv. 'Beltrán' and 'Seda', commercial trees found in Huaral Province, Lima, Peru. Mature seeds were washed with detergent and water, and sectioned to obtain the explant with the embryo and part of the endosperm. The explant were surface-sterilised by immersion in a $5.25 \%(\mathrm{w} / \mathrm{v})$ commercial bleach solution for 2, 3 and 5 min in several treatments and then washed with running sterilised water for 3 to 5 minutes to remove the $\mathrm{NaOCl}$ (Table 1), before being individually inoculated into glass vessels $(10 \times 6 \mathrm{~cm})$ containing $50 \mathrm{~mL}$ MS (Murashige, Skoog 1962) medium including 0.0, 0.1 and $1.0 \mathrm{mg} \mathrm{L}^{-1}$ gibberellic acid $\left(\mathrm{GA}_{3}\right)$. Likewise, in a separate experiment carried out to obtain ex vitro rootstocks, mature seeds were also washed with detergent and water, and placed to germinate in substrate S1, which contained vermicompost and sand 1:1. The vermicompost was an organic fertiliser obtained from the California red worm (Eisenia foetida).

\section{Scion source}

The in vitro seedlings used as scion were obtained from P. lucuma seeds cv. 'Beltrán' and 'Seda', commercial trees. $P$. lucuma seeds were selected and sterilized following the same protocol used to disinfect rootstocks, and individually inoculated into test tubes $(25 \times 150 \mathrm{~mm})$ containing 25 mL MS medium supplemented with $0.1 \mathrm{mg} \mathrm{L}^{-1} \mathrm{GA}_{3}$. Sterile apical tips and axillar buds (1.5 to $2.0 \mathrm{~cm}$ in length) were obtained directly from the apical bud and nodal segments, respectively.

In ex vitro experiments, young offshoots were collected from 15-year-old trees of lucumo cv. 'Seda' growing in the Botanical Garden of the Universidad Nacional Pedro Ruiz Gallo, Lambayeque, Peru; as before we used apical tips obtained from rootstocks germinated in substrate S1 for the latter experiments. These explants were washed with running water for $10 \mathrm{~min}$, surface-sterilised in $10 \mathrm{~mL}$ of commercial bleach solution $(5.25 \% \mathrm{NaOCl}) 1.0 \mathrm{~L}^{-1}$ in sterile distilled water for $10 \mathrm{~min}$, and rinsed five times with sterile water.

\section{In vitro micrografting procedure and maintenance of micrograft}

Under aseptic conditions, shoots of uniform length (2.0 $\mathrm{cm}$ ) and diameter (1 to $2 \mathrm{~mm}$ ), aged 8 weeks, were selected from in vitro cultures and used as rootstocks and scions in micrografting. The rootstock was decapitated, and a $5 \mathrm{~mm}$ vertical incisión was made from the top of each rootstock, and the scion was cut at $45^{\circ}$ angle (wedge shape) from the base. The joined part was ligated with aseptic aluminum foil $(1.0 \times 0.5 \mathrm{~cm})$ or with aseptic wires of cooper. To prevent dehydration of in vitro grafts, before micrografting, the cutting area of the scion was immersed in BAP solution $\left(1.5 \mathrm{mg} \mathrm{L}^{-1}\right)$. The micrografted seedlings were cultured into two different MS medium containing $3.53 \mathrm{~g} \mathrm{~L}^{-1} \mathrm{CaCl}_{2} \mathrm{H}_{2} \mathrm{O}$ and $0.1 \mathrm{mg} \mathrm{L}^{-1} \mathrm{GA}_{3}(\mathrm{MM}-1)$ and $3.53 \mathrm{~g} \mathrm{~L}^{-1} \mathrm{CaCl}_{2} \mathrm{H}_{2} \mathrm{O}, 0.1$ $\mathrm{mg} \mathrm{L}^{-1} \mathrm{GA}_{3}$ and $0.4 \mathrm{mg} \mathrm{L}^{-1} \mathrm{IBA}$ (MM-2).

The procedures for the ex vitro micrografting were similar to the ones used for the in vitro micrografting. The number of successful micrografts was recorded 12 weeks after micrografting and the percentage of success was recorded.

\section{Media and culture conditions}

In this study, in all experiments the basal MS medium was supplemented with the vitamins myo-inositol $100 \mathrm{mg}$ $\mathrm{L}^{-1}$ and thiamine $\mathrm{HCl} 1.0 \mathrm{mg} \mathrm{L}^{-1}$ and $6.0 \mathrm{~g} \mathrm{~L}^{-1}$ agar. The $\mathrm{pH}$ of all media was adjusted to $5.8 \pm 0.1$, with $\mathrm{KOH}$ and $\mathrm{HCl}$, prior to autoclaving at $121{ }^{\circ} \mathrm{C}$ at $105 \mathrm{kPa}$ for $20 \mathrm{~min}$. Each treatment comprised 10 explants and was performed twice. The plant material was kept in a growth room with a controlled temperature of $26 \pm 2{ }^{\circ} \mathrm{C}$, relative air humidity of approximately $80 \%$, and photoperiod of $16 \mathrm{~h}$ light with $60 \mu \mathrm{mol} \mathrm{m}{ }^{-2} \mathrm{~s}^{-1}$ photosynthetic photon flux density via cool white fluorescent lamps $(40 \mathrm{~W})$. 

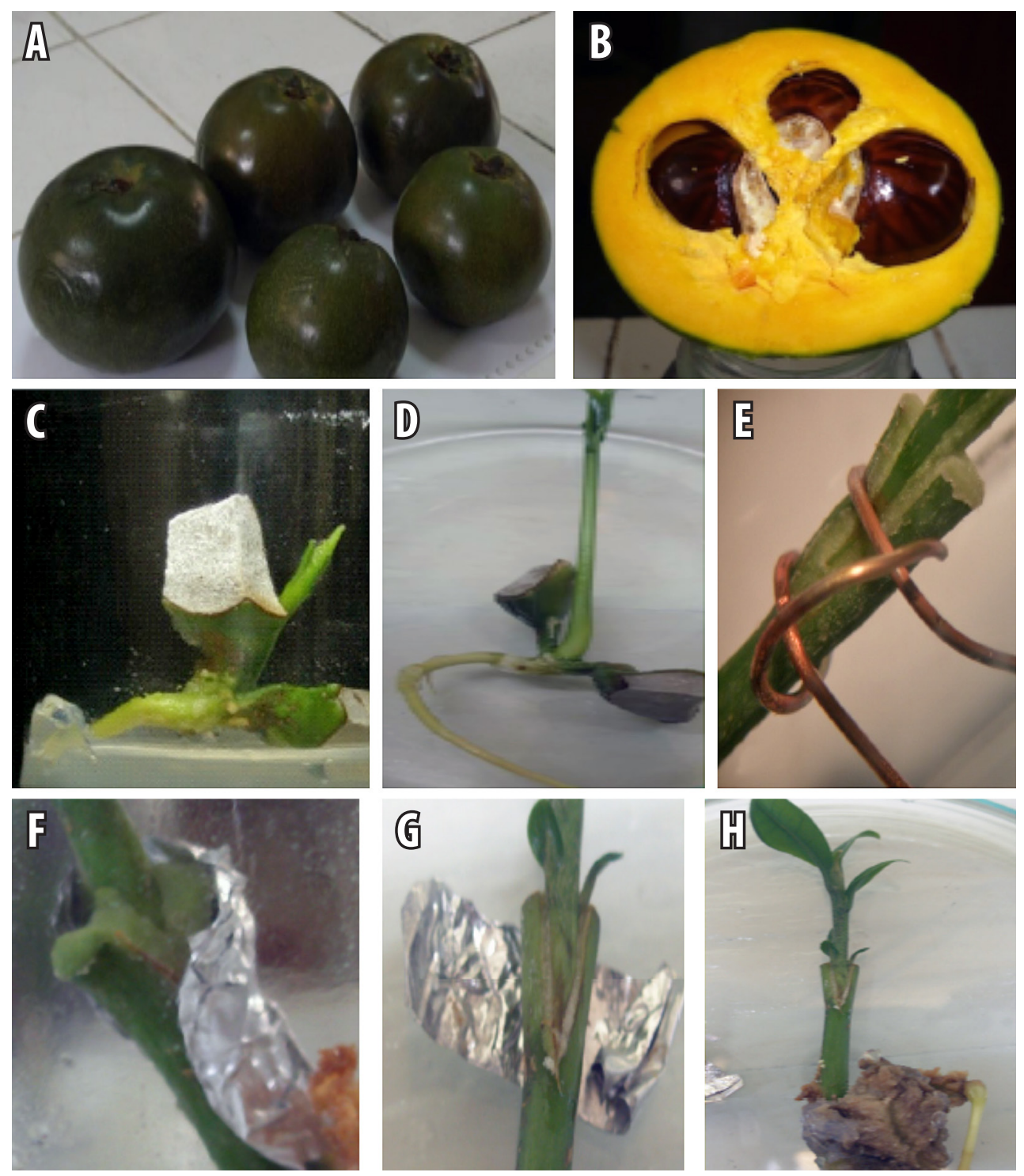

Fig. 1. Microgfrating of lucumo (Pouteria lucuma) cv. 'Seda'. A, mature fruits; B, fruit with mature seeds; C, seed germination; D, seedling used as rootstock and the shoot tip as scion; E, grafting with cooper wire; F, grafting with aluminum foil; G, micrografting after six weeks; $\mathrm{H}$, micrografting with callus and roots.

\section{Rooting}

Root induction was not necessary since the rootstocks retained their roots during the micrografting process.

\section{Statistical analysis}

The success, cicatrisation and elongation rate of micrografted plantlets were recorded on micrografts after 12 weeks. Data was statistically analysed by analysis of variance (ANOVA), and the Tukey's test $(=0.05 \%)$ was applied to separate the means, using SPSS 11.5 software (SPSS, USA).

\section{Results and discussion}

\section{Culture initiation}

In this experiment, $70 \%$ contamination was observed when the explants were treated with $5.25 \%$ sodium hypochlorite for $3 \mathrm{~min}$ and then washed two times with distilled water; however, 80 to $90 \%$ disinfection of the explants was achieved with $5.25 \%$ sodium hypochlorite for $5 \mathrm{~min}$ and then washing three times with distilled water, or with $5.25 \%$ sodium hypochlorite for $3 \mathrm{~min}$, followed by washing two times with distilled water, or with $5.25 \%$ sodium hypochlorite for $3 \mathrm{~min}$ and washing two times with distilled water (Table 1). This resulted in a significant reduction in the level of damage (apical necrosis and browning), to just $10 \%$ of explants, and scarce contamination (20\%) was observed (Table 1).

In culture initiation and axillary bud growth of purple pitahaya (Hylocereus costaricensis) larger explants (5 to 7 $\mathrm{cm}$ length) was sterilized with alkaline detergent for 10 $\mathrm{min}$, followed by immersion in $70 \%(\mathrm{v} / \mathrm{v})$ ethanol for 15 to $30 \mathrm{~s}$, a mixture of fungicide and bactericide for $30 \mathrm{~min}$, 
Table 1. Contamination and tissue damage suffered by explants after pre-treatment and disinfection, 15 days after in vitro culture initiation of Pouteria lucuma

\begin{tabular}{|c|c|c|c|c|}
\hline \multirow[t]{2}{*}{ Protocol of disinfection } & \multicolumn{2}{|c|}{ Contamination (No./\%) } & \multicolumn{2}{|c|}{$\begin{array}{l}\text { Apical necrosis and browning } \\
\qquad(\mathrm{No} / \%)\end{array}$} \\
\hline & + & - & + & - \\
\hline $\begin{array}{l}\text { Clorox }^{\infty} \text { (sodium hypochlorite at } 5.25 \% \text { ) for } 3 \mathrm{~min} \\
\text { washed two times with distilled water }\end{array}$ & $7 / 70.0$ & $3 / 30.0$ & - & - \\
\hline $\begin{array}{l}\text { Clorox }^{\infty} \text { (sodium hypochlorite at } 5.25 \% \text { ) for } 5 \text { min } \\
\text { washed three times with distilled water }\end{array}$ & $1 / 10.0$ & $9 / 90.0$ & $4 / 40.0$ & $6 / 60.0$ \\
\hline $\begin{array}{l}\text { Clorox }^{\circ} \text { (sodium hypochlorite at } 5.25 \% \text { ) for } 3 \mathrm{~min} \\
\text { washed two times with distilled water }\end{array}$ & $2 / 20.0$ & $8 / 80.0$ & $1 / 10.0$ & $9 / 90.0$ \\
\hline
\end{tabular}

Clorox $^{\oplus}$ (sodium hypochlorite at $5.25 \%$ ) for $2 \mathrm{~min}$

and disinfection in sodium hypochlorite $(1.0 \% \mathrm{v} / \mathrm{v})$ for 15 min, which resulted in a significant reduction of the level of damage to only $16 \%$ of the explants, and the abscence of contamination (Viñas et al. 2012). These results were very similar to the ones observed in our study, where the disinfection method we used produced contamination rates comparable with the best results published for in vitro trees species using field explants (Iş̧kalan et al. 2011; Cortizo et al. 2004).

Other damaging characteristics were observed minimally in our study. Those characteristics were apical necrosis; browning of the cut surfaces, which inhibits the growth and development of new cells and results in poor graft union; and tissue blackening, which commonly results in the death of very small scions.

\section{Shoots height and node formation}

The sterile explants, seeds with zygotic embryo, and partial endosperm $\left(1.0\right.$ to $\left.1.5 \mathrm{~cm}^{3}\right)$, were cultured into the MS medium containing $0.0,0.1,1,0 \mathrm{mg} \mathrm{L}{ }^{-1} \mathrm{GA}_{3}$ separately. From the results presented in Table 2, it appears that the maximum shoot height $(6.1 \pm 1.2$ and $5.2 \pm 0.4 \mathrm{~cm})$ of $\mathrm{cv}$. 'Beltrán' and 'Seda' was observed in the presence of 0.1 and $1.0 \mathrm{mg} \mathrm{L}^{-1} \mathrm{GA}_{3}$, respectively, and the lowest shoot height was observed on media supplemented with $0.1 \mathrm{mg} \mathrm{L}^{-1} \mathrm{GA}_{3}$ in the cv. 'Seda' $(4.6 \pm 0.7 \mathrm{~cm})$. In the abscence of growth regulators, shoot growth in both cv. 'Beltrán' and 'Seda'it was also observed The results showed that using $\mathrm{GA}_{3}$ not was absolutely necessary for shoot growth. Likewise, the maximum average number of nodes formed per explant was observed on media supplemented with $0.1 \mathrm{mg} \mathrm{L}^{-1} \mathrm{GA}_{3}$ in both var. 'Beltrán' and 'Seda' with 7 and 6 nodes, respectively
(Table 2). In the abscence of growth regulators, minimum formation of nodes in both cultivars was observed.

\section{Shoot and root formation}

In both cv. 'Beltrán' and 'Seda', the average number of shoots per explant decreased with increase of the $\mathrm{GA}_{3}$ concentration from 0.0 to $1.0 \mathrm{mg} \mathrm{L}^{-1}$, although only one shoot was formed at $1.0 \mathrm{mg} \mathrm{L}^{-1}$. To form two shoots it was necessary to add 0.1 or $1.0 \mathrm{mg} \mathrm{L}^{-1} \mathrm{GA}_{3}$ (Table 3); however, to form one and two roots it was not necessary to add $\mathrm{GA}_{3}$ (Table 3).

In contrast, induction and shoot growth is minimal in herbaceous plants grown in in vitro cultures of woody species. For instance, in the rejuvenation process of mature lentisk (Pistacia lentiscus) by micrografting, the highest shoot number and shoot height per explant in the female genotype was 2.2 and $1.4 \mathrm{~cm}$, respectively, obtained with 1.0 $\mathrm{mg} \mathrm{L}^{-1} \mathrm{GA}_{3}+1.0 \mathrm{mg} \mathrm{L}^{-1} \mathrm{BA}$ (Onay et al. 2016).

\section{Height of micrografts}

After 12 weeks of micrografting, maximum shoot height $(3.04 \mathrm{~cm})$ was observed in the MM-2 culture medium supplemented with $0.1 \mathrm{mg} \mathrm{L}^{-1} \mathrm{GA}_{3}$ and $0.4 \mathrm{mg} \mathrm{L}^{-1} \mathrm{IBA}$ in the 'Seda' $\times$ 'Seda' (rootstock $\times$ scion) combination. With respect to the development of microscions, the best result $(2.76 \mathrm{~cm})$ was obtained when they were immersed in 1.5 $\mathrm{mg} \mathrm{L}{ }^{-1} \mathrm{BAP}$ in the MM-2 culture medium, and with respect to the holding grafts, the best result $(3.02 \mathrm{~cm})$ was observed with aluminum foil use in the MM-2 culture medium (Table 4).

Wedge or cleft grafting had to be performed to prepare rootstock and scion for micrografting (surface placement

Table 2. Effect of $\mathrm{GA}_{3}$ in the shoot height and nodes formation of Pouteria lucuma. Each treatment consisted of 10 explants and was performed twice. Values with different letters in the same column are significantly different $(P \leq 0.05)$

\begin{tabular}{lcccc} 
Culture medium $\left(\mathbf{m g ~ L}^{-1}\right)$ & \multicolumn{2}{c}{ Shoot height $(\mathbf{c m})$} & \multicolumn{2}{c}{ Node formation (No.) } \\
\cline { 2 - 5 } & 'Beltrán' & 'Seda' & 'Beltrán' & 'Seda' \\
T1: MS + 0.0 GA & $4.4 \pm 0.8 \mathrm{~b}$ & $4.9 \pm 0.3 \mathrm{a}$ & 4 & 4 \\
T2: $\mathrm{MS}+0.1 \mathrm{GA}_{3}$ & $6.1 \pm 1.2 \mathrm{a}$ & $4.6 \pm 0.7 \mathrm{ab}$ & 7 & 6 \\
T3: $\mathrm{MS}+1.0 \mathrm{GA}_{3}$ & $5.4 \pm 0.6 \mathrm{ab}$ & $5.2 \pm 0.4 \mathrm{a}$ & 5 & 5
\end{tabular}


Table 3. Effect of $\mathrm{GA}_{3}$ in the shoots and roots formation of Pouteria lucuma. ${ }^{\star}$ Number of shoots and roots formed (1-3). Each treatment consisted of 10 explants and was performed twice.

\begin{tabular}{|c|c|c|c|c|c|c|c|c|c|c|c|c|}
\hline \multirow[t]{3}{*}{ Culture medium $\left(\mathrm{mg} \mathrm{L}^{-1}\right)$} & \multicolumn{6}{|c|}{ Shoot formation (\%) } & \multicolumn{6}{|c|}{ Root formation (\%) } \\
\hline & \multicolumn{3}{|c|}{ 'Beltrán' } & \multicolumn{3}{|c|}{ 'Seda' } & \multicolumn{3}{|c|}{ 'Beltrán' } & \multicolumn{3}{|c|}{ 'Seda' } \\
\hline & $1^{*}$ & 2 & 3 & 1 & 2 & 3 & $1^{*}$ & 2 & 3 & 1 & 2 & 3 \\
\hline $\mathrm{T} 1: \mathrm{MS}+0.0 \mathrm{GA}_{3}$ & 80 & 20 & 0 & 80 & 10 & 10 & 60 & 20 & 10 & 60 & 10 & 0 \\
\hline $\mathrm{T} 2: \mathrm{MS}+0.1 \mathrm{GA}_{3}$ & 60 & 40 & 0 & 70 & 30 & 0 & 80 & 10 & 0 & 80 & 10 & 0 \\
\hline $\mathrm{T} 3: \mathrm{MS}+1.0 \mathrm{GA}_{3}$ & 60 & 40 & 0 & 70 & 30 & 0 & 70 & 10 & 10 & 70 & 0 & 0 \\
\hline
\end{tabular}

method), because it had to be ensured that the thickness of rootstock and the scion material were large enough to allow us to make a wedge on the scion material (Hussain et al. 2014), and for the reason that a firm contact between rootstock and scion, with the consequent formation of callus, ensured the success of the process, as has been observed in in vitro micrografting of pistachio (Pistacia vera) on wild pistachio rootstocks (Canan et al.2006). On the other hand, several techniques have been developed to hold grafts together until fusion takes place. Those techniques include translucent silicon tubing, elastic strip, filter paper bridge, and glass tubing, nylon bands, aluminum foil tubes, dual layer apparatus of aluminum foil and absorbent paper (Hussain et al. 2014). In our study, a new technique, which uses copper wires, was tested.

\section{Cicatrisation and callus formation}

In the scale of 1 to 3 , grafting success was determined by cicatrisation and callus induction. The greatest cicatrization, and consequently the greatest callus induction, was observed in the MM-2 culture medium, when cooper wire was used (2.92) as holding grafts, and immersion in $1.5 \mathrm{mg}$ $\mathrm{L}^{-1}$ BAP (2.91) as pre-treatment, for the combinations of genotypes rootstock $\times$ scion ( 2.86 to 2.88 ); however, these results lacked statistical significance (Table 5).

In a study of in vitro grafting of grape with phylloxera resistant rootstock cultivars, it was reported that grafting success was determined by callus formation and rooting (Kim et al. 2005). Likewise, in grafting of Sedum and Solanum, Moore and Walker (1983) observed that adjacent callus masses tended to graft successfully in the abscence of vascular differentiation, and in Opuntia callus formation was determined to be independent of grafting success, although callus growth constituted a key factor in the development of the graft union (Jeffree, Yeoman 1983). In the micrografting of mature stone pine (Pinus pinea) trees, the proliferation of an intermediate callus between rootstock and scion during the first week of cultivation was also a determining event (Cortizo et al. 2004).

\section{Micrograft development}

The success of micrografting primarily depends on the grafting technique. In our study cleft grafting, where the joined parts were ligated with aseptic aluminum foil or aseptic cooper wire, proved to be the most successful and efficient method for in vitro micrografting. The grafting survival rate was 87.5 and $83.3 \%$ for genotypes 'Seda' $\times$ 'Beltrán' (rootstock $\times$ scion) with cooper wire and 'Seda' $\times$ 'Seda' also with cooper wire, respectively (Table 6). These combinations were the two best among the 16 combinations tried. Grafting success was determined by callus formation and rooting. Callus tended to be formed at the junction of a graft union, arising from the living cells of both, scion and rootstock. In addition, in both MM-1 and MM-2 culture

Table 4. Effect of several factors on elongation $(\mathrm{cm})$ of micrografted plants of Pouteria lucuma. Data recorded on the 12 weeks; 10 replicates per treatment and repeated twice. Bt, cv. 'Beltrán' and Sd, cv. 'Seda. Each treatment consisted of 10 explants and was performed twice. Values with different letters in the same column are significantly different $(P \leq 0.05)$

\begin{tabular}{|c|c|c|c|c|}
\hline \multirow[t]{2}{*}{ Culture medium } & \multicolumn{4}{|c|}{ Holding grafts } \\
\hline & \multicolumn{2}{|c|}{ Aluminum foil } & \multicolumn{2}{|c|}{ Cooper wire } \\
\hline MM-1 & \multicolumn{2}{|c|}{$0.93 \mathrm{a}$} & \multicolumn{2}{|c|}{2.11 ef } \\
\hline \multirow[t]{3}{*}{ MM-2 } & \multicolumn{2}{|c|}{$3.02 \mathrm{i}$} & \multicolumn{2}{|c|}{$2.30 \mathrm{f}$} \\
\hline & \multicolumn{4}{|c|}{ Pre-treatment (immersion in $1.5 \mathrm{mg} \mathrm{L}^{-1} \mathrm{BAP}$ ) } \\
\hline & \multicolumn{2}{|c|}{ With BAP } & \multicolumn{2}{|c|}{ Without BAP } \\
\hline MM-1 & \multicolumn{2}{|c|}{$1.84 \mathrm{~d}$} & \multicolumn{2}{|c|}{$1.20 \mathrm{~b}$} \\
\hline \multirow[t]{3}{*}{ MM-2 } & \multicolumn{2}{|c|}{$2.76 \mathrm{gh}$} & \multicolumn{2}{|c|}{$2.56 \mathrm{~g}$} \\
\hline & \multicolumn{4}{|c|}{ Genotype } \\
\hline & $\mathbf{B t} \times \mathbf{B t}$ & $\mathrm{Sd} \times \mathrm{Sd}$ & $\mathrm{Sd} \times \mathrm{Bt}$ & Bt $\times$ Sd \\
\hline MM-1 & $1.74 \mathrm{~d}$ & $1.99 \mathrm{de}$ & $1.50 \mathrm{c}$ & $0.85 \mathrm{a}$ \\
\hline MM-2 & $2.11 \mathrm{ef}$ & $3.04 \mathrm{i}$ & $2.57 \mathrm{~g}$ & 2.91 hi \\
\hline
\end{tabular}


Table 5. Effect of several factors on cicatrization ( 1 to 3 scale) of micrografted plants of Pouteria lucuma. Data recorded on the 12 weeks; 10 replicates per treatment and repeated twice. Bt, cv. 'Beltrán' and Sd, cv. 'Seda'. Each treatment comprised 10 explants and was performed twice. Values with different letters in the same column are significantly different $(P \leq 0.05)$

\begin{tabular}{|c|c|c|c|c|}
\hline \multirow[t]{2}{*}{ Culture medium } & \multicolumn{4}{|c|}{ Holding grafts } \\
\hline & \multicolumn{2}{|c|}{ Aluminum foil } & \multicolumn{2}{|c|}{ Cooper wire } \\
\hline MM-1 & \multicolumn{2}{|c|}{$2.87 \mathrm{c}$} & \multicolumn{2}{|c|}{$2.54 \mathrm{a}$} \\
\hline \multirow[t]{3}{*}{ MM-2 } & \multicolumn{2}{|c|}{$2.82 \mathrm{bc}$} & \multicolumn{2}{|c|}{$2.92 \mathrm{c}$} \\
\hline & \multicolumn{4}{|c|}{ Pre-treatment (immersion in $1.5 \mathrm{mg} \mathrm{L}^{-1} \mathrm{BAP}$ ) } \\
\hline & \multicolumn{2}{|c|}{ With BAP } & \multicolumn{2}{|c|}{ Without BAP } \\
\hline MM-1 & \multicolumn{2}{|c|}{$2.86 \mathrm{c}$} & \multicolumn{2}{|c|}{$2.54 \mathrm{a}$} \\
\hline \multirow[t]{3}{*}{ MM-2 } & \multicolumn{2}{|c|}{$2.91 \mathrm{c}$} & \multicolumn{2}{|c|}{$2.82 \mathrm{bc}$} \\
\hline & \multicolumn{4}{|c|}{ Genotype } \\
\hline & $\mathrm{Bt} \times \mathrm{Bt}$ & $\mathrm{Sd} \times \mathrm{Sd}$ & $\mathrm{Sd} \times \mathrm{Bt}$ & Bt $\times$ Sd \\
\hline MM-1 & $2.59 \mathrm{ab}$ & $2.70 \mathrm{abc}$ & $2.69 \mathrm{abc}$ & $2.83 \mathrm{bc}$ \\
\hline MM-2 & $2.86 \mathrm{c}$ & $2.87 \mathrm{c}$ & $2.88 \mathrm{c}$ & $2.88 \mathrm{c}$ \\
\hline
\end{tabular}

medium the survival rate, after grafting, was $52.6 \%$ and $54.1 \%$, respectively (Table 6).

In in vitro grafting of grape with phylloxera-resistant rootstock cultivars, the grafting success was determined by callus formation and rooting; in this study, the rootstock 'Couderc 3309' was successful in rooting, callus formation, and growth with all scion types, and among the rootstocks or scions, was found that grafting compatibilities ranged between 11\% ('Tamnara'/'Rupestris du Lot') and 100\% ('Schyler'/'Couderc 3309') (Kim et al. 2005). In our study, the grafting survival was about $50 \%$ in all combinations of genotypes (rootstock $\times$ scion).

On the other hand, in the micrografting of mature stone pine (Pinus pinea) trees, after the removal of the sheath of the needle a cut was made to excise the brachyblast, and then a V-shaped cut of $2 \mathrm{~mm}$ ortogonal to the plane of the needle was performed, and scions were inserted into the split and the edges of the hypocotyl were held together with a ring made of $1 \mathrm{~mm}$ wall chromatography tubing (Cortizo et al.2004). In that study, the average developmental success (out of contamination) of the protocol was $43 \%$, accounting for the five clones assayed, which was a result slightly lower

Table 6. Success rate and growth of Pouteria lucuma shoots after 12 weeks micrografting. +, with pretreatment; -, without pretreatment. $\mathrm{Al}$, aluminum foil; $\mathrm{Cu}$, cooper wire. MM-1: MS, $3.53 \mathrm{~g} \mathrm{~L}^{-1} \mathrm{CaCl}_{2} \mathrm{H}_{2} \mathrm{O}$ and $0.1 \mathrm{mg} \mathrm{L} \mathrm{GA}_{3}$; MM-2: $\mathrm{MS}, 3.53 \mathrm{~g} \mathrm{~L}^{-1} \mathrm{CaCl}_{2} \mathrm{H}_{2} \mathrm{O}, 0.1 \mathrm{mg} \mathrm{L}^{-1}$ $\mathrm{GA}_{3}$ and $0.4 \mathrm{mg} \mathrm{L}^{-1} \mathrm{IBA}$. Cont., contamination; Ap. necr., apical necrosis; Graf. surv., grafting survival. Bt, cv. 'Beltrán' and Sd, cv. 'Seda'. Each treatment consisted of 10 explants and was performed twice. Values with different letters in the same column are significantly different $(P \leq 0.05)$

\begin{tabular}{|c|c|c|c|c|c|c|c|c|}
\hline \multirow{3}{*}{$\begin{array}{l}\text { Genotype } \\
(\text { rootstock } \times \text { scion })\end{array}$} & \multirow{3}{*}{$\begin{array}{l}\text { Holding } \\
\text { grafts }\end{array}$} & \multirow{3}{*}{$\begin{array}{c}\text { Pre-treatment } \\
\text { (immersion in } 1.5 \mathrm{mg} \\
\mathrm{L}^{-1} \mathrm{BAP} \text { ) }\end{array}$} & \multicolumn{6}{|c|}{ Culture medium } \\
\hline & & & \multicolumn{3}{|c|}{ MM-1 } & \multicolumn{3}{|c|}{ MM-2 } \\
\hline & & & Cont. & Ap. necr. & Graf. surv. & Cont. & Ap. necr. & Graf. surv \\
\hline $\mathrm{Bt} \times \mathrm{Bt}$ & $\mathrm{Al}$ & - & 10.0 & 40.0 & $50.0 \mathrm{a}$ & 00.0 & 33.3 & $66.7 \mathrm{a}$ \\
\hline $\mathrm{Bt} \times \mathrm{Bt}$ & $\mathrm{Al}$ & + & 12.5 & 62.5 & $25.0 \mathrm{c}$ & 16.7 & 33.3 & $50.0 \mathrm{~b}$ \\
\hline $\mathrm{Bt} \times \mathrm{Bt}$ & $\mathrm{Cu}$ & - & 14.3 & 28.6 & $57.1 \mathrm{a}$ & 20.0 & 20.0 & $60.0 \mathrm{a}$ \\
\hline $\mathrm{Bt} \times \mathrm{Bt}$ & $\mathrm{Cu}$ & + & 00.0 & 60.0 & $40.0 \mathrm{~b}$ & 00.0 & 62.5 & $37.5 \mathrm{c}$ \\
\hline $\mathrm{Sd} \times \mathrm{Sd}$ & $\mathrm{Al}$ & - & 00.0 & 40.0 & $60.0 \mathrm{a}$ & 14.3 & 28.6 & $57.1 \mathrm{~b}$ \\
\hline $\mathrm{Sd} \times \mathrm{Sd}$ & $\mathrm{Al}$ & + & 00.0 & 80.0 & $20.0 \mathrm{c}$ & 00.0 & 37.5 & $62.5 b$ \\
\hline $\mathrm{Sd} \times \mathrm{Sd}$ & $\mathrm{Cu}$ & - & 00.0 & 50.0 & $50.0 \mathrm{~b}$ & 20.0 & 20.0 & $60.0 \mathrm{~b}$ \\
\hline $\mathrm{Sd} \times \mathrm{Sd}$ & $\mathrm{Cu}$ & + & 12.5 & 25.0 & $62.5 c$ & 16.7 & 00.0 & $83.3 \mathrm{a}$ \\
\hline $\mathrm{Sd} \times \mathrm{Bt}$ & $\mathrm{Al}$ & - & 40.0 & 40.0 & $20.0 \mathrm{~d}$ & 33.3 & 16.7 & $50.0 \mathrm{bc}$ \\
\hline $\mathrm{Sd} \times \mathrm{Bt}$ & $\mathrm{Al}$ & + & 42.8 & 14.3 & $42.8 \mathrm{c}$ & 00.0 & 20.0 & $80.0 \mathrm{a}$ \\
\hline $\mathrm{Sd} \times \mathrm{Bt}$ & $\mathrm{Cu}$ & - & 00.0 & 12.5 & $87.5 a$ & 20.0 & 20.0 & $60.0 \mathrm{~b}$ \\
\hline $\mathrm{Sd} \times \mathrm{Bt}$ & $\mathrm{Cu}$ & + & 20.0 & 20.0 & $60.0 \mathrm{~b}$ & 00.0 & 60.0 & $40.0 \mathrm{~cd}$ \\
\hline $\mathrm{Bt} \times \mathrm{Sd}$ & $\mathrm{Al}$ & - & 00.0 & 40.0 & $60.0 \mathrm{~b}$ & 25.0 & 25.0 & $50.0 \mathrm{~b}$ \\
\hline $\mathrm{Bt} \times \mathrm{Sd}$ & $\mathrm{Al}$ & + & 33.3 & 33.3 & $33.4 \mathrm{~d}$ & 40.0 & 20.0 & $40.0 \mathrm{c}$ \\
\hline $\mathrm{Bt} \times \mathrm{Sd}$ & $\mathrm{Cu}$ & - & 00.0 & 18.2 & $81.8 \mathrm{a}$ & 40.0 & 00.0 & $60.0 \mathrm{a}$ \\
\hline $\mathrm{Bt} \times \mathrm{Sd}$ & $\mathrm{Cu}$ & + & 16.7 & 33.3 & $50.0 \mathrm{bc}$ & 25.0 & 50.0 & $25.0 \mathrm{~d}$ \\
\hline Total & & & 11.2 & 36.2 & 52.6 & 16.3 & 29.6 & 54.1 \\
\hline
\end{tabular}


than obtained in our work.

The micrografting technique improved the viability of the explant, although the result was not statistically significant. Likewise, the pretreatment of the scion allowed to select the viable apex and helped their development, which greatly improved the micrografting success especially when very small sized shoot apices were used (Hussain et al. 2014). In our study, pre-treatment of scion by immersion in $1.5 \mathrm{mg} \mathrm{L}^{-1}$ BAP improved the viability of the explant, although the result was not statistically significant. MosellaChancel et al. (1979) reported 64\% successful micrografts in peach when they were pre-treated with zeatin $(0.1 \mathrm{mg}$ $\left.\mathrm{L}^{-1}\right)$ for $48 \mathrm{~h}$ compared to the $21.7 \%$ successful micrografts obtained when they used no pretreatment.

We obtained the same results using exvitro micrografting and in vitro micrografting. Ex vitro acclimated plants need to be tested to determine their real agronomic value. To our knowledge, this is the first report on in vitro grafting for $P$. lucuma.

\section{Conclusion}

In the present study, an efficient, simple, and reproducible in vitro micrografting protocol for Pouteria lucuma was established. Cleft grafting proved to be the most successful and efficient method for in vitro micrografting, where the joined part was ligated with aseptic aluminum foil or aseptic cooper wire. P. lucuma is one of the most widespread native species widely cultivated in wet montane and cloud forest of the Peru.

\section{Acknowledgements}

The autors are grateful to the Prof. Alain Monsalve Mera for English improvement, and the Prof. Jorge Chanamé Céspedes for the statistical analysis.

\section{References}

Amiri M.E. 2006. In vitro techniques to study the shoot-tip grafting of Prunus avium L. (cherry) var. Seeyahe Mashad. J. Food Agric. Environ. 4: 151-154.

Brako L., Zarucchi J. 1993. Catálogo de Plantas con Flores y Gimnospermas del Perú. Missouri Botanical Garden, St. Louis. Monogr. Syst. Bot. Missouri Bot. Gard. 45: 365-374.

Canan C., Mehmet O., Hakan T., Kami S., Elman I. 2006. In vitro micrografting of pistachio (Pistacia vera L.) var. Siirt, on wild pistachio rootstocks. J. Cell Mol. Biol. 5: 25-31.

Channuntapipat C., Sedgley M., Collins G. 2003. Micropropagation of almond cultivars Nonpareil and Ne Plus Ultra and the hybrid rootstock Titan X Nemaguard. Sci. Hortic. 98: 473-484.

Cortizo M., Alonso P., Fernández B., Rodríguez A., Centeno M.L., Ordás R.J. 2004. Micrografting of mature Stone pine (Pinus pinea L.) trees. Ann. For. Sci. 61: 843-845.

Hartmann H.T., Kester D.E., Davies F.T., Geneve R.L. 2002. Plant propagation, Principles and Practices. $7^{\text {th }}$ Ed. New Jersey: Printice Hall.
Hussain G., Wani M.S., Mir M.A., Rather Z.A., Bhat K.M. 2014. Micrografting for fruit crop improvement. Afr. J. Biotechnol. 13: 2474-2483.

Işıkalan C., Namli S., Akbas F., Ak B.E. 2011. Micrografting of almond (Amygdalus communis) cultivar 'Nonpareil'. Austr. J. Crop Sci. 5: 61-65.

Jeffree C.E., Yeomam M.M. 1983. Development of intercellular connection between opposing cells in a graft union. New Phytol. 93: 491-509.

Jonard R. 1986. Micropropagation and its applications to tree improvement. In: Bajaj Y.P.S. (ed) Biotechnology in Agriculture and Forestry. Vol. 1. Trees I. Springer-Verlag, Berlin, pp. 31-48.

Jonard R., Hugard J., Macheix J.J., Martínez J., Mosella-Chancel L., Poessel J.l., Villemur P. 1983. In vitro micrografting and its applications to fruit science. Sci. Hortic. 20: 147-159.

Kim C.S., Lee C.H., Park H.S., Lee G.P. 2005. In vitro grafting of grape with phylloxera resistant rootstock cultivars. Vitis 44: 195-196.

Miguel C.M., Druart P., Oliveira M.M. 1996. Shoot regeneration from adventitious buds induced on juvenile and adult almond (Prunus dulcis Mill.) explants. In Vitro Cell. Dev. Biol. Plant 32: 148-153.

Mondal T.K., Parathiray S., Mohan Kumar P.2005. Micrografting: A technique to shorten the hardening time of micropropagated shoots of tea (Camellia sinensis (L.) O. Kuntze). Sri Lanka J. Tea Sci. 70: 5-9.

Monteuuis O. 2012. In vitro grafting of woody species. Propag. Ornam. Plants 12: 11-24.

Moore R., Walker D.B. 1983. Studies of vegetative compatibilityincompatibility in higher plants. VI. Grafting of Sedum and Solanum callus tissue in vitro. Protoplasma 115: 114-121.

Mosella-Chancel L., Riedel M., Jonard R. 1979. Sur les ameliorations apportes aux techniques de microgreffagedes apexes in vitro chez les arbres fruitiers cas du pecher (Prunus persica B.). C. R. Acad. Sci. Paris D 289: 505-508.

Murashige T., Skoog F. 1962. A revised medium for rapid growth and bioassays with tobacco tissue cultures. Physiol. Plant. 15: 437-497.

Murashige T., Bitters W.P., Rangan E.M., Nauer E.M., Roistacher C.N., Holliday P.B. 1972. A technique of shoot apex grafting and its utilization towards recovering virus-free citrus clones. HortScience 7: 118-119.

Navarro L. 1988. Application of shoot-tip grafting in vitro to woody species. Acta Hort. 227: 43-55.

Parkinson M., O’Neil C.M., Dix P.J. 1990. Grafting in vitro. In: Pollard J.W., Walker J.M. (eds) Methods in Molecular Biology. Vol. 6. Plant Cell and Tissue Culture. Human Press, New Jersey, pp. 105-111.

Pennington T.D., Reynel C., Daza A. 2004. Trees of Peru. Ed. dh. $817 \mathrm{p}$.

Roistacher C.N., Navarro L., Murashige T. 1976. Recovery of citrus selections free of several viruses, exocortis viroid, and by shoot-tip grafting in vitro. $7^{\text {th }}$ IOCV conference www.ivia. es/iocv/archivos/proceedings VII/7th 186_193.pdf

Thimmappaiah Puthra G.T., Anil S.R. 2002. In vitro grafting of cashew (Anacardium occidentale L.). Sci. Hortic. 92: 117-182.

Viñas M., Fernández-Brenes M., Azofeifa A., Jiménez V.M. 2012. In vitro propagation of purple pitahaya (Hylocereus costaricensis [F.A.C. Weber] Britton \& Rose) cv. Cebra. In Vitro Cell. Dev. Biol. Plant 48: 469-477.

Yildirim H., Onay A., Süzerer V., Tilkat E., Ozden-Tokatli Y., 
Akdemir H. 2010. Micrografting of a almond (Prunus dulcis Mill.) cultivars 'Ferragnes' and 'Ferraduel'. Sci. Hortic. 125: 361-367.
Zhu B., Cao H-N, Zong C-W, Piao R-Z, Chen L., Zhou L. 2007. Micrografting technology in grapevine (Vitis vinifera L.). Fruit Veget. Cereal Sci. Biotechnol. 1: 60-63. 